\title{
Yield and Yield Attributing Traits in Diverse Genotypes of Brinjal (Solanum melongena L.)
}

\author{
Sanjay Kumar", Dhananjay Sharma, Amit Dixit and Arvind Kumar Janghel \\ Department of vegetable science, I.G.K.V., Raipur, Chhattisgarh, India \\ *Corresponding author
}

\section{Keywords}

Evaluation, Brinjal, Quality and yield

Article Info

Accepted:

10 September 2018

Available Online:

10 October 2018

\section{A B S T R A C T}

Brinjal (Solanum melongena L.) cultivar were investigate for growth, fruit yield and its component characters at All India Coordinated Research Project on Vegetable Crop at Horticultural Research cum Instructional Farm, Department of vegetable Science, Indira Gandhi Krishi Vishwavidyalaya, Raipur (C.G.) during the rabi season of 2016-17. The study revealed that highly significant differences were observed for all the traits. Selection of suitable parents is an important criterion for success of crop improvement programme. Superior genotypes in terms of highest marketable fruit yield per hectare (q) was observed in 2016/BRLVAR-3 (663.07 q) followed by 2014/BRLVAR-1 $(567.00$ q) and 2014/BRLVAR-4 (545.10 q). The maximum fruit yield per plant was found in 2016/BRLVAR-3 (3.73 kg) followed by 2014/BRLVAR-1 (3.19 kg), 2014/BRLVAR-4 $(3.07 \mathrm{~kg})$. The highest plant height was observed in 2014/BRLVAR-4 $(90.5 \mathrm{~cm})$ followed by 2016/BRLVAR- $2(69.74 \mathrm{csm})$. The maximum number of primary branches per plant was observed in 2016/BRLVAR-4 (6.67) followed by 2016/BRLVAR-8 (5.80), The earliest flowering was observed for 2016/BRLVAR-8 (30.33 days) followed by 2016/BRLVAR-2 (32.67 days). The minimum number of days to $50 \%$ flowering was found in 2016/BRLVAR - 8 (50.00) it and 2016/BRLVAR-1 followed by 2016/BRLVAR2 (51.00). The maximum number of flower per cluster was observed in Punjab Sadabahar (4.06) followed by 2016/BRLVAR-4 (3.96). The maximum number of fruits per cluster was observed in Kashi Taru (3.50) followed by 2016/BRLVAR-4 (3.46). The maximum average fruits per cluster was observed in 2015/BRLVAR-1 (3.36), and 2016/BRLVAR-9 (3.26), while the minimum fruit per cluster was observed in 2015/BRLVAR-2 (2.04). Minimum number of day to maturity is found in 2015/BRLVAR-5 (65.34 days) followed by 2015/BRLVAR-2 (68.00 days), Maximum number of fruits per plant was found in 2015/BRLVAR-1 (15.06) followed by 2016/BRLVAR-3 (14.80).

\section{Introduction}

Brinjal (Solanum melongena Linn.) commonly known as eggplant/aubergine is an important vegetable belongs to the family Solanaceae. It is grown mainly for its tender and immature fruits. They are primarily used as cooked vegetable in different parts of the world. It is also used for making pickles and dehydrated products.

Brinjal is a popular vegetable, highly cosmopolitan and is considered as poor man's crop, thereby grown in almost all parts of 
India except higher altitudes, all round the year. It is a popular and principle fruit vegetable grown in India and other parts of tropical and subtropical world but in temperate regions. Eggplant fruits could be consumed raw as snacks by both adult and children. The fruits are cooked and used in the preparation of sauces for cocoyam and yam (Onwuka, 2005). India is the centre of variation for brinjal and is recommended even for patients with diabetes, asthma, cholera and bronchitis (Medina et al., 2014). It is grown mainly during warm season (Rai et al., 1995). Vavilov (1928) has mentioned that its centre of origin was the Indo-Burma region.

The increasing demand for eggplants has gone along with the rapid growth of population. This is due to the increasing awareness toward the nutritional and health benefit of eggplant in fulfilling the nutritional requirement of the family (Jumini and Marliah, 2009). It contains high amount of carbohydrates $(6.4 \%)$, protein $(1.3 \%)$, fat $(0.3 \%)$, calcium $(0.02 \%)$, phosphorus $(0.02 \%)$, iron $(0.0013 \%)$ and other mineral matters. It also contains $\beta$-carotene $(34 \mathrm{mg})$, riboflavin $(0.05 \mathrm{mg})$, thiamine $(0.05$ $\mathrm{mg})$, niacine $(0.5 \mathrm{mg})$ and ascorbic acid $(0.9$ $\mathrm{mg}$ ) per $100 \mathrm{~g}$ of fruit (Kandoliya et al., 2015).

\section{Materials and Methods}

The present investigation entitled "Yield and Yield Attributing Traits in Diverse Genotypes of brinjal (Solanum melongena L.)" was conducted at All India Coordinated Research Project on Vegetable Crop at Horticultural Research cum Instructional Farm, Department of vegetable Science, Indira Gandhi Krishi Vishwavidyalaya, Raipur(C.G.) during the rabi season of 2016-17.

The place of investigation is situated in the central part of Chhattisgarh at $21^{\circ} 16^{\prime} \mathrm{N}$ latitude, $81^{\circ} 36^{\prime} \mathrm{E}$ longitude and at an altitude of $289.56 \mathrm{~m}$ from mean sea level. The climate of Raipur is characterized as dry sub-humid with normal rainfall of $1200-1400 \mathrm{~mm}$ per annum, mostly concentrated during the monsoon months i.e., 15 June to September. It comes under the seventh agro-climatic zone of country, which is eastern plateau and hills. The soil of experimental field was clay-loam in texture with average fertility which is locally known as Dorsa in the region. The experimental field was cropped with crop like cabbage, chili, tomato, pea etc. during last five years.

The experiment was laid out in Randomized Block Design (RBD) with three replications with above 17 treatments with plot size of $3.75 \mathrm{~m}$. x $3.0 \mathrm{~m}$ and plant spacing are $75 \times 60$ $\mathrm{cm}$. five plants are randomly selected in each plot to representative sample for studying growth performance, viz., by recording observations on Yield per hectare (q), Yield per plant $(\mathrm{g})$, Plant height $(\mathrm{cm})$, Number of primary branches per plant, Days to first flowering, Days to $50 \%$ flowering, Number of flower per cluster, Number of fruits per cluster, Average fruits per cluster, Days to maturity, Number of fruits per plant.

\section{Results and Discussion}

The observation on five plants from each genotype in all three replication for fruit yield and its components were used for calculating the mean performance, the observations were first averaged for five plant taken randomly for each genotype in each replication and were later averaged over the replication. The mean performance of different genotypes is presented in Table 2 and described below:

\section{Plant height (cm)}

The plant height ranged from $54.04 \mathrm{~cm}$ (2015/BRRVAR-4) to $90.5 \mathrm{~cm}$ (2014/BRLVAR-4) with overall mean of $63.79 \mathrm{~cm}$. The highest plant height was 
observed in 2014/BRLVAR-4 $(90.5 \mathrm{~cm})$ followed by 2016/BRLVAR- $2(69.74 \mathrm{~cm})$, 2015/BRLVAR-5 (69.63 cm.) while lowest plant height was found in 2015/BRLVAR-4 $(54.04 \mathrm{~cm}$.)

\section{Number of primary branches per plant}

The number of primary branches per plant varied from 3.73 (2016/BRLVAR- 1) to 6.67 (2016/BRLVAR-4) with overall mean of 4.76. The maximum number of primary branches per plant was observed in 2016/BRLVAR-4 (6.67) followed by 2016/BRLVAR-8 (5.80), and 2014/BRLVAR-4(5.33) while minimum number of primary branches was found in 2016/BRLVAR- 1 (3.73).

\section{Days to first flowering}

Days to first flowering from the date of transplanting were recorded and it ranged from 30.33 (2016/BRLVAR-8) days to 43.67 (2014 BRLVAR-4) days with a general mean of 38.78 days.

The earliest flowering was observed for 2016/BRLVAR-8 (30.33 days) followed by 2016/BRLVAR-2 (32.67 days), 2016/BRLVAR-8 (34.33 days), and 2016/BRLVAR-1 (36.00 days) whereas, the delayed flowering was noted in 2014/BRLVAR-4.

\section{Days to 50\% flowering}

Days to $50 \%$ flowering from the date of transplanting were recorded and it ranged from 50.00 (2016/BRLVAR-8) days to 66.33 (2015/BRLVAR- 4 and 2015/BRLVAR-3) day with an overall mean of 59.21 days. The minimum number of days to $50 \%$ flowering was found in 2016/BRLVAR - 8 (50.00) it and 2016/BRLVAR-1 followed by 2016/BRLVAR-2 (51.00) and the 2016/BRLVAR-7 (52.00) Maximum number of days to $50 \%$ flowering was found in 2015/BRLVAR- 4 (66.33), which are similar to 2015/BRLVAR-3 (66.33).

\section{Number of flower per cluster}

The number of flower per cluster ranged from 2.50 (2016/BRLVAR-9), to 4.06 (Punjab Sadabahar) with an overall mean of (3.34).

The maximum number of flower per cluster was observed in Punjab Sadabahar (4.06) followed by 2016/BRLVAR-4 (3.96) and Kashi Taru (3.86) similar to 2016/BRLVAR-3 (3.86), and 2015/BRLVAR-1 (3.76) and the minimum number of flower per cluster were found 2016/BRLVAR-9 (2.50).

\section{Number of fruits per cluster}

The number of fruits per cluster ranged from 2.93 (2016/BRLVAR-2) to 3.50 (Kashi Taru) with an overall mean of 3.23 .

The maximum number of fruits per cluster was observed in Kashi Taru (3.50) followed by 2016/BRLVAR-4 (3.46), 2016/BRLVAR-7 (3.40). The minimum number of fruits per cluster was found 2016/BRLVAR-2 (2.93).

\section{Average fruits per cluster}

The average fruits per cluster varied from 2.04 (2015/BRLVAR-2) to 3.36 (2015/BRLVAR1) with an overall mean of 2.74. The maximum fruits per cluster was observed in 2015/BRLVAR-1 (3.36), and 2016/BRLVAR9 (3.26), while the minimum fruit per cluster was observed in 2015/BRLVAR-2 (2.04).

\section{Days to maturity}

The character days to maturity varied from 65.34 days (2015/BRLVAR-5) to 101.66 days (2016/BRLVAR-9) with overall mean of (87.66 days). 
Table.1 Details of experimental material (Treatments)

\begin{tabular}{|l|l|l|}
\hline S. No. & Genotype & Source \\
\hline 1. & 2014 / BRLVAR -1 & AICRP on Vegetable Crops \\
\hline 2. & 2014 / BRLVAR -2 & AICRP on Vegetable Crops \\
\hline 3. & 2014 / BRLVAR -4 & AICRP on Vegetable Crops \\
\hline 4. & 2015 / BRLVAR -1 & AICRP on Vegetable Crops \\
\hline 5. & 2015 / BRLVAR -2 & AICRP on Vegetable Crops \\
\hline 6. & 2015 / BRLVAR -3 & AICRP on Vegetable Crops \\
\hline 7. & 2015 / BRLVAR -4 & AICRP on Vegetable Crops \\
\hline 8. & 2015 / BRLVAR -5 & AICRP on Vegetable Crops \\
\hline 9. & 2016 / BRLVAR -1 & AICRP on Vegetable Crops \\
\hline 10. & 2016 / BRLVAR -2 & AICRP on Vegetable Crops \\
\hline 11. & 2016 / BRLVAR -3 & AICRP on Vegetable Crops \\
\hline 12. & 2016 / BRLVAR -4 & AICRP on Vegetable Crops \\
\hline 13. & 2016 / BRLVAR -7 & AICRP on Vegetable Crops \\
\hline 14. & 2016 / BRLVAR -8 & AICRP on Vegetable Crops \\
\hline 15. & 2016 / BRLVAR -9 & AICRP on Vegetable Crops \\
\hline 16 & Kashi Taru & IIVR, Varanasi \\
\hline 17. & Punjab Sadabahar & PAU, Ludhiana \\
\hline
\end{tabular}

Table.2 Mean performances for fruit yield and its components along with quality traits in brinjal

\begin{tabular}{|c|c|c|c|c|c|c|c|c|c|c|c|}
\hline $\begin{array}{l}\text { Characters } \\
\text { Genotypes }\end{array}$ & $\begin{array}{l}\text { 1. Days to } \\
\text { first } \\
\text { flower }\end{array}$ & $\begin{array}{c}\text { 2- Days } \\
\text { to } 50 \% \\
\text { flowering }\end{array}$ & $\begin{array}{c}\text { 3-Plant } \\
\text { height } \\
(\mathrm{cm} .)\end{array}$ & $\begin{array}{l}\text { 4-No. of } \\
\text { prim. }\end{array}$ & $\begin{array}{l}\text { 5- No. } \\
\text { of } \\
\text { flow./ } \\
\text { clust. }\end{array}$ & $\begin{array}{l}\text { 6- No. } \\
\text { of } \\
\text { fruit/ } \\
\text { cluster }\end{array}$ & $\begin{array}{c}\text { 7- } \\
\text { Averg. } \\
\text { Fruit } \\
\text { /cluster }\end{array}$ & $\begin{array}{l}\text { 12- Days } \\
\text { to } \\
\text { maturity }\end{array}$ & $\begin{array}{c}\text { 13- No. } \\
\text { of fruit } \\
\text { per } \\
\text { plant }\end{array}$ & $\begin{array}{l}\text { 14-Yield } \\
\text { per } \\
\text { hectare } \\
\text { (q) }\end{array}$ & $\begin{array}{l}15- \\
\text { Yield } \\
\text { per } \\
\text { plant } \\
(\mathrm{kg})\end{array}$ \\
\hline 2014 / BRLVAR-1 & 39.00 & 61.67 & 66.63 & 4.46 & 3.00 & 3.10 & 2.26 & 87.67 & 13.73 & 567.01 & 3.19 \\
\hline 2014 / BRLVAR-2 & 42.67 & 65.33 & 67.4 & 4.46 & 2.73 & 3.10 & 2.73 & 88.00 & 13.00 & 472.10 & 2.66 \\
\hline 2014 / BRLVAR-4 & 43.67 & 65.33 & 90.5 & 5.33 & 2.86 & 3.23 & 2.90 & 91.67 & 13.46 & 545.10 & 3.07 \\
\hline 2015 / BRLVAR-1 & 41.00 & 63.67 & 62.86 & 4.20 & 3.70 & 3.16 & 3.36 & 76.00 & 15.06 & 475.49 & 2.68 \\
\hline 2015 / BRLVAR-2 & 41.00 & 63.67 & 57.20 & 3.67 & 2.64 & 3.06 & 2.04 & 68.00 & 10.13 & 367.28 & 2.03 \\
\hline 2015 / BRLVAR-3 & 41.67 & 66.33 & 58.90 & 4.40 & 3.86 & 3.13 & 3.07 & 71.34 & 17.13 & 522.60 & 2.94 \\
\hline 2015 / BRLVAR-4 & 42.00 & 66.33 & 54.04 & 4.13 & 3.20 & 3.43 & 2.56 & 79.00 & 12.86 & 416.42 & 2.34 \\
\hline 2015 / BRLVAR-5 & 42.67 & 62.00 & 69.63 & 4.60 & 3.10 & 3.20 & 2.30 & 65.34 & 12.06 & 386.25 & 2.17 \\
\hline 2016 / BRLVAR-1 & 41.33 & 63.00 & 63.00 & 3.73 & 3.00 & 3.16 & 2.60 & 97.34 & 8.06 & 318.59 & 1.79 \\
\hline 2016 / BRLVAR-2 & 42.67 & 65.33 & 68.70 & 4.73 & 3.00 & 2.93 & 2.56 & 100.33 & 8.06 & 297.69 & 1.67 \\
\hline 2016 / BRLVAR-3 & 36.00 & 50.00 & 61.70 & 5.06 & 3.86 & 3.43 & 2.83 & 94.33 & 14.80 & 663.07 & 3.73 \\
\hline 2016 / BRLVAR-4 & 32.67 & 51.00 & 69.73 & 6.67 & 3.96 & 3.46 & 2.70 & 96.33 & 7.13 & 280.19 & 1.58 \\
\hline 2016 / BRLAVR-7 & 35.33 & 54.00 & 58.16 & 5.20 & 3.40 & 3.40 & 2.80 & 101.33 & 7.13 & 262.06 & 1.47 \\
\hline 2016 / BRLVAR-8 & 30.33 & 50.00 & 58.03 & 5.80 & 4.06 & 3.31 & 2.80 & 95.33 & 7.83 & 296.32 & 1.67 \\
\hline 2016 / BRLVAR-9 & 35.33 & 52.00 & 57.23 & 4.00 & 2.50 & 3.20 & 2.70 & 101.66 & 13.33 & 486.63 & 2.74 \\
\hline Kashi Taru & 34.33 & 53.00 & 61.63 & 4.66 & 3.86 & 3.50 & 3.10 & 93.33 & 11.26 & 404.20 & 2.27 \\
\hline Punjab Sadabahar & 37.33 & 54.33 & 59.16 & 5.8 & 4.06 & 3.13 & 3.26 & 83.33 & 11.80 & 410.28 & 2.31 \\
\hline Mean (x) & 38.784 & 59.215 & 63.797 & 4.760 & 3.34 & 3.23 & 2.74 & 87.666 & 11.713 & 421.487 & 2.37 \\
\hline SEm \pm & 1.326 & 1.485 & 3.051 & 0.344 & 0.376 & 0.189 & 0.180 & 2.926 & 0.574 & 27.965 & 0.157 \\
\hline $\mathrm{CD}(\mathrm{p}=\mathbf{0 . 0 5})$ & 3.820 & 4.278 & 8.790 & 0.992 & 1.083 & 0.546 & 0.519 & 8.429 & 1.655 & 80.559 & 0.453 \\
\hline CV (\%) & 5.923 & 4.344 & 8.284 & 12.531 & 19.48 & 9.650 & 11.39 & 5.781 & 8.496 & 11.492 & 11.492 \\
\hline
\end{tabular}


Minimum number of day to maturity is found in 2015/BRLVAR-5 (65.34 days) followed by 2015/BRLVAR-2 (68.00 days) and 2015/BRLVAR-3 (71.34 days), 2015/BRLVAR-1 (76.00 days) whereas, the highest day to maturity was recorded In 2016/BRLVAR-9 (101.66 days).

\section{Number of fruits per plant}

The number of fruits per plant varied from 7.13 (2016/BRLVAR-7 and 2016/BRLVAR4) to $17.13(2015 /$ BRLVAR-3) with overall mean of (11.71).

Maximum number of fruits per plant was found in 2015/BRLVAR-1 (15.06) followed by 2016/BRLVAR-3 (14.80), 2014/BRLVAR- 1 (13.73), while minimum number of fruits per plant was found in 2016/BRLVAR-7 and 2016/BRLVAR-4 (7.13).

\section{Yield per plant (kg)}

Character fruit yield per plant $(\mathrm{kg})$ had a varied from $1.47 \mathrm{~kg}$ (2016/BRLVAR- 7) to $3.73 \mathrm{~kg}$ (2016/BRLVAR-3) with an overall mean of $2.36 \mathrm{~kg}$. The maximum fruit yield per plant was found in 2016/BRLVAR-3 $(3.73 \mathrm{~kg}$ ) followed by 2014/BRLVAR-1 (3.19 $\mathrm{kg}), \quad 2014 / \mathrm{BRLVAR}-4 \quad(3.07 \quad \mathrm{~kg})$ and 2015/BRLVAR-3 (2.94 kg) while minimum fruit yield per plant was found in 2016/BRLVAR- 7 (1.47 kg).

\section{Yield per hectare (q/ha)}

The marketable fruit yield per hectare (q) varied from 262.06 q (2016/BRLVAR-7) to 663.07 q (2016/BRLVAR-3) with an overall mean of 424.46 q. The highest marketable fruit yield per hectare (q) was observed in 2016/BRLVAR-3 (663.07 q) followed by 2014/BRLVAR-1 (567.00 q), 2014/BRLVAR-4 (545.10 q) while lowest marketable fruit yield per hectare (q) was observed in 2016/BRLVAR-7 (130.00 q). 2016/BRLVAR- 7 (262.06 q).

It could be concluded from present findings that considerable range of variation for most of the characters indicating considerably high amount of variability is present in the experimental material under study. It is evident from the investigation that various treatments resulted significant variation on vegetative characters like Yield per hectare (q), Yield per plant $(\mathrm{g})$, Plant height $(\mathrm{cm})$, Number of primary branches per plant, Days to first flowering, Days to $50 \%$ flowering, Number of flower per cluster, Number of fruits per cluster, Average fruits per cluster, Days to maturity, Number of fruits per plant. highest marketable fruit yield per hectare (q) was observed in 2016/BRLVAR-3 (663.07 q), The maximum fruit yield per plant was found in 2016/BRLVAR-3 (3.73 kg), The highest plant height was observed in 2014/BRLVAR$4(90.5 \mathrm{~cm})$, The maximum number of primary branches per plant was observed in 2016/BRLVAR-4 (6.67), The earliest flowering was observed for 2016/BRLVAR-8 (30.33 days), The minimum number of days to $50 \%$ flowering was found in 2016/BRLVAR - 8 (50.00), The maximum number of flower per cluster was observed in Punjab Sadabahar (4.06), The maximum number of fruits per cluster was observed in Kashi Taru (3.50), The maximum average fruits per cluster was observed in 2015/BRLVAR-1 (3.36), and 2016/BRLVAR-9 (3.26), Minimum number of day to maturity is found in 2015/BRLVAR-5 (65.34 days), Maximum number of fruits per plant was found in 2015/BRLVAR-1 (15.06).

\section{Acknowledgement}

The author is highly grateful to Department of Vegetable science, Indira Gandhi Krishi 
Vishwavidyalaya, Raipur (C.G.), for providing the varieties and technical support for research work.

\section{References}

Jumini and A. Marliah. (2009). Growth and yield of eggplant due to application of leaf fertilizer Gandasil D and Harmonik growth regulators. Jurnal Floratek. 4: 73-80.

Kandoliya UK, Bajaniya VK, Bhadja NK, Bodar NP, Golakiya BA. (2015). Antioxidant and nutritional components of eggplant (Solanum melongena L) fruit grown in Saurastra region. Int. J Curr. Microbiol. App. Sci. 4(2):806813.
Medina GN, Rangel DM, Bejar AG, Aguilar GG, Heredia B, Sanudo MB et al., (2014). Nutritional and nutraceutical components of commercial eggplant types grown in Sinaloa, Mexico. Not. Bot. Hort. Agrobo. 42(2):538-544.

Onwuka, G. I. (2005), Food Analysis and Instrumentation. Theory and Practices, Food Science Journal, 8(5): 3-35

Rai, M., (1995). Catalogue on Eggplant (Solanum melongena L.) germplasms part-I. National Bureau of Plant Genetic Resources, Pusa Campus, New Delhi, pp. 1-3,

Vavilov, N.I. 1928. Proceedings of 5th International Congress of Genetics, New York: 342-369.

\section{How to cite this article:}

Sanjay Kumar, Dhananjay Sharma, Amit Dixit and Arvind Kumar Janghel. 2018. Yield and Yield Attributing Traits in Diverse Genotypes of Brinjal (Solanum melongena L.). Int.J.Curr.Microbiol.App.Sci. 7(10): 983-988. doi: https://doi.org/10.20546/ijcmas.2018.710.109 